\title{
An Overview of the Economics of Sports Gambling and an Introduction to the Symposium
}

\section{Victor Matheson ${ }^{1}$}

Published online: 4 January 2021

(c) EEA 2021

\section{Gambling in the Ancient World}

Gambling likely predates recorded history. The casting of lots (from which we get the modern term "lottery") is mentioned both in the Old and New Testaments of the Bible, most famously when Roman soldiers cast lots for the clothes of Jesus during his crucifixion. In Greek mythology, Hades, Poseidon, and Zeus divided the heavens, the seas, and the underworld through a game of chance.

Organized sports also have a long history. The Ancient Olympic Games date back to 776 BCE and persisted until 394 AD. The Circus Maximum in Rome, the home of horse and chariot racing events as well as gladiatorial contests for over one thousand years, was originally constructed around $500 \mathrm{BCE}$, and the Colosseum in Rome began hosting sporting events including gladiator fights in 80 AD. Variations of the ball game Pitz were played in Mesoamerica for nearly 3000 years beginning as early as 1400 BCE (Matheson 2019).

Given the prevalence of both sporting contests and gambling across many ancient civilizations, it is natural to conclude that the combined activity of sports gambling also has a long history. And, indeed it is widely reported that gambling was a popular activity at the Olympics and other ancient Panhellenic events in Greece and at the racing and fighting contests in ancient Rome. Problems associated with gambling were also widely reported. As early as $388 \mathrm{BCE}$, the boxer Eupolus of Thessaly was known to have paid opponents to throw fights in the Olympics. Rampant gambling in Rome led Caesar Augustus (c. BCE 20) to limit the activity to only a week-long festival called "Saturnalia" celebrated around the time of the winter solstice, while Emperor Commodus (AD 192) turned the royal palace into a casino and bankrupted the Roman Empire along the way (Matheson et al. 2018).

Just as in the modern day, gambling was often looked down upon by societal leaders in antiquity. Horace (Ode III., 24; 23 BCE) wrote, "The young Roman is no longer devoted to the manly habits of riding and hunting; his skills seem to develop more in

Victor Matheson

vmatheso@holycross.edu

1 College of the Holy Cross, Worcester, USA 
the games of chances forbidden by law." Juvenal (Satire I, 87; 101 AD), well-known for coining the term "bread and circuses" wrote, "Never has the torrent of vice been to irresistible or the depths of avarice more absorbing, or the passion for gambling more intense. None approach nowadays the gambling table with the purse; they must carry their strongbox. What can we think of these profligates more ready to lose 100,000 than to give a tunic to a slave dying with cold." (Matheson 2019).

\section{Gambling in Renaissance and Pre-industrial Revolution Europe}

Gambling in Europe persisted into the Middle Ages and Renaissance. For example, although the true origins of the famous columns in Venice's Piazza San Marco are lost to the mysteries of time, at least one history suggests they were erected around 1127 by Nicholas Barattieri, who was rewarded for this task by the local government with an exclusive right to operate a gaming table between the columns, an activity otherwise officially prohibited in the Republic (Schiavon 2020).

However, without the large sporting events of the ancient world, gambling turned more toward to precursors of modern casino games. Indeed, the gambling that occurred in the "small houses" or "casini" of the city of Venice is the origin of the modern term "casino," and in 1638 Il Ridotto, "the Private Room," became the first public, legal casino in the region (Schwarz 2006).

Until the formation of professional sports leagues in the mid- to late nineteenth century, horse racing was the predominant type of sports gambling across Europe and North America. The Newmarket Racecourse near Cambridge, UK, was founded in 1636 although races at the location date to even earlier. The racetrack was frequented by King Charles II earning horse racing the title of "the Sport of Kings" (Black 1891). The first racetrack in North America was established on Long Island in 1665, and horse racing has persisted in the USA since that time.

Prior to the mid-1800s, bets in horseracing were handled by bookmakers who set odds on individual races. This carries risk for the bookmaker who may be forced to pay out large winning bets as well as the bettor who may find that the bookmaker lacks the funds to cover all payouts. This problem was solved in 1867 in Paris when Joseph Oller, who later went on to open the famous Parisian nightclub the Moulin Rouge, developed pari-mutuel betting.

Under pari-mutuel betting, the returns are based not on independent odds set by a bookmaker but instead are endogenously generated by the gamblers themselves based upon the number and size of the bets made on various race participants (Canymeres 1946). This betting system rapidly became wildly popular for racing in Europe and USA and remains the standard for horse racing today throughout the world.

\section{Gambling Throughout US History}

Gambling was a common activity throughout colonial and early American history. Lotteries funded activities such as the original European settlement at Jamestown, the operations of prestigious universities such as Harvard and 
Princeton, and construction of historic Faneuil Hall in Boston. Card rooms were not unusual at taverns and roadhouses across the country, and the activity moved west onto riverboats and into saloons as westward expansion occurred during the 1800s (Grote and Matheson 2017).

However, the late 1800s and early 1900 witnessed a widespread decline the legality of all types of gambling throughout the USA. In the sports realm, by 1900 betting on horse races was made illegal except in Kentucky and Maryland, states that to this day host two of the three Triple Crown events in American horseracing, the Kentucky Derby and the Preakness Stakes. States began to relegalize gambling on horse racing in the 1930s as a method of economic stimulus during the Great Depression. Total horse racing handle peaked in the 1970s and has generally declined since that time due to increased competition from alternative forms of gambling such as state lotteries and casinos (and, in fact, many racetracks nationwide, known as "racinos," are permitted to offer alternative forms of gambling such as slot machines on their grounds (Nash 2009)). In 2019, horse racing's handle in the USA totaled $\$ 11.0$ billion (Jockey Club 2020).

The birth of professional sports leagues in the USA also gave immediate rise to new betting opportunities, as well as problems associated with corruption. The oldest professional league in the USA, baseball's National League, formed in 1876 , and by 1877 the Louisville Grays ended the season mired in a betting scandal and ceased operations. Similarly in football, the Ohio League, a forerunner to the modern National Football League (NFL), began play in 1903, and by 1906, the league was embroiled in a match fixing scandal between the Canton Bulldogs and the Massillon Tigers (Grote and Matheson 2017).

During the early years of professional sports leagues in the USA, betting on games, although generally illegal like most gambling in the period, was common either through direct bets made with bookies or through "pool cards" allowing gamblers to bet on a slate of games. Nevada, which in 1931 became the first state to relegalize most forms of gambling, authorized sports gambling in 1949, but high tax rates on wagers prevented major casinos from running sports books until 1974. Following the elimination of a $10 \%$ tax on sports gambling revenues in the state, the sport betting handle rose dramatically from $\$ 825,767$ in 1973 to $\$ 3,873,217$ in 1974 , to $\$ 26,170,328$ in 1975 (Grote and Matheson 2017). By 2019, Nevada's 192 sportsbooks took in $\$ 5.3$ billion in wagers or roughly $2.7 \%$ of total gaming revenues for the state (Nevada Gaming Control Board 2019).

While Nevada remained the only state offering full sports books, Montana, Oregon, and Delaware all offered pool cards through their state lotteries beginning in the 1970s. Montana first offered legal pool cards in 1974. Delaware followed in 1976 (even winning a court case against the NFL for the right to offer sports gambling), but its games folded in the following year due to difficulties in adhering to the state's statutory guidelines about lottery contributions to state coffers. The Oregon Lottery sold NFL pool cards from 1998 to 2007 and National Basketball Association (NBA) game tickets in 1998 and 1999 (although the NBA ticket did not include games featuring Portland's local NBA team). Pressure from the National Collegiate Athletic Association (NCAA) eventually led the state to terminate its sports gambling offerings under the threat of losing the opportunity 
to host NCAA post-season men's basketball tournament (March Madness) games (Grote and Matheson 2017).

The Professional and Amateur Sports Protection Act (PAPSA), passed in 1992, prohibited states from legalizing sports gambling in any form including lotteries, casinos, and tribal casinos while grandfathering in the four states with existing sports gambling operations. In mid 2010s, the state of New Jersey, in an effort to revive its flagging casinos in Atlantic City, sued to overturn PAPSA, and in May 2018, the US Supreme Court declared PAPSA unconstitutional. While this ruling did not legalize sports gambling in any states, it did allow states the option to legalize sports gambling if they so choose. This symposium examines some of the economic issues facing the sports gambling industry as the American market opens up.

\section{Issues Facing the New Sports Gambling Industry}

The first and perhaps easiest question facing the industry is how quickly and how widely will sports gambling be adopted by states? Here it seems clear that sports gambling will follow the pattern seen in lottery and casino adoption, although almost certainly at a much faster pace. As noted by Garrett and Marsh (2002), once states began to legalize state lotteries, neighboring states began to feel pressure to legalize their own state games or otherwise lose consumer spending to lottery players crossing the border to buy tickets.

By 2020, this pressure had led all but 6 states to adopt lotteries after the first state lottery was reestablished in New Hampshire in 1964. Among the holdouts, Alaska and Hawaii are protected geographically from cross-border purchases, Nevada's powerful gambling industry has successfully prevented the adoption of a state-sponsored competitor, and conservative religious cultures in Alabama, Mississippi, and Utah have stopped lotteries there. (Religious concerns have not stopped Mississippi from legalizing sports gambling, however. Perhaps God just really wants to put a few bucks down on Ole Miss to upset the Tide this year.)

With respect to sports gambling, New Jersey and Delaware legalized the activity immediately upon the Court's decision in 2018, and many states followed suit. By the end of 2020, 20 states and the District of Columbia had legalized sports gambling, 6 had legalized sports gambling but were pending launch, and over 20 more states were considering legislation (Rodenberg 2020). It appears that sports gambling will soon be legal nearly nationwide.

The next big question facing the industry is assessing the potential size of the sports betting market. If sports wagering is restricted to in-person betting at existing casinos, the impact of nationwide legalization is likely to be quite modest. Extrapolating Nevada's sport wagering data to the national casino market suggests that nationwide legalization might lead to as much as $\$ 20$ billion in annual wagers and just under $\$ 1$ billion in net casino revenues. While these figures may seem high, they pale in comparison to gambling figures in the UK where sports betting has been legal (although highly regulated) since 1960 and is widely available through over 8300 (as of March 2019) small, commercial betting shops spread throughout the country as well as through online betting sites. 
In the most recent fiscal year prior to shutdowns caused by the COVID-19 pandemic, in-person betting shops in the UK generated $\$ 3.7$ billion and online gambling generated another $\$ 2.8$ billion in net gambling revenues (UK Gambling Commission 2020). This implies that UK bettors placed roughly $\$ 130$ billion in wagers in 2019 or about $\$ 2000$ per person in the country. If industry were to achieve a similar level of popularity in the US market, this would suggest over $\$ 600$ billion in annual wagers and $\$ 32$ billion in net sport gambling revenue. The $\$ 32$ billion figure would be roughly twice the net gambling revenue generated by state lotteries across the country and slightly less than the $\$ 42$ billion in net casino gaming revenue generated across the USA. Such revenue figures would likely only be possible with widespread adoption of legalized mobile sports gambling as well as within-game betting on individual plays as opposed to wagering solely on game outcomes.

Obviously, another major question facing the industry is the extent to which expanded access to sports gambling will bring in new players to the gambling industry overall or whether it will simply cannibalize existing gambling options such as state lotteries, horse racing, or casino gaming. The first paper in this symposium examines this topic by analyzing the determinants of sport gambling handle and its effects on other casino gaming at West Virginia casinos during roughly the first year of legalized sports betting in the state (Humpheys 2021). Brad Humphreys finds that the introduction of sports gambling seems to have significantly decreased overall state gaming tax revenues as gains from sport gambling taxes were far outweighed by decreases in tax revenues from video lottery terminals.

Of course, even if the problem of cannibalization is avoided by sports gambling attracting a new customer base, this is not without its own set of problems as sports wagering may introduce an entirely new population to the problems associated with pathological gambling and problem gaming (McGowan 2014). The second paper in this symposium examines health outcomes in Canada related to participation in gambling activities (Humphreys et al. 2021). Brad Humphreys, John Nyman, and Jane Ruseski show that recreational gambling has either no effect or even actually reduces the probability of having certain chronic health conditions and has a positive impact on life satisfaction suggesting the possibility that expanded sport gambling in the USA may not be associated with significant adverse health outcomes.

Legalized sports gambling is certain to bring about winners and losers. As noted above, depending on the level of cannibalization, other forms of gambling are likely to be losers such as horse racing, which is likely to continue its long-term decline in gambling handle (Nash 2009), and potentially casino gaming as identified by Humphreys (2021) in this symposium. On the other hand, sports book operators and mobile application developers are likely winners, so casinos themselves may either be either winners or losers in sports gambling legalization. It is interesting to note that established casinos have not been the only players to enter the online sports gambling market. In many states, the companies FanDuel and DraftKings, who prior to sports gambling legalization operated online fantasy football competitions of controversial legality, have already been able to leverage their fan bases in the online fantasy sports gaming communities into more traditional online sports gambling opportunities. 
The sports leagues themselves may also be either winners or losers. Historically in the USA, leagues strongly opposed legal sports betting due to the potential for corruption. The history of sports in the USA is littered with betting scandals from the earliest days of the previously mentioned Louisville Grays and Canton Bulldogs to the infamous 1919 "Black Sox" World Series scandal to the 1948 NCAA basketball point-shaving scheme to the more recent actions of Major League Baseball (MLB) player and manager Pete Rose or NBA referee Tim Donaghy.

More recently, however, leagues have become more supportive of sports betting. In part, leagues acknowledge that legal betting markets make it easier for regulators to uncover suspicious betting behavior that could suggest corruption. More importantly, teams and leagues have also slowly recognized the potential for higher fan interest if fans have the opportunity to gamble on games. There is no doubt that the NCAA can attribute a significant portion of its 23-year, $\$ 19.6$ billion television contract for March Madness on the popularity of "bracket pools," and likewise the NFL understands the degree to which the explosion of fantasy football leagues has increased the popularity of its games. Humphreys et al. (2013) developed evidence of a significant correlation between betting and television viewership for regular season men's NCAA basketball games.

Furthermore, the dramatic increase in professional athlete salaries over the past several decades in the USA has reduced worries of corruption. It is highly unlikely that star players in any major US league would jeopardize their massive earning potential as an athlete by accepting a bribe to alter a game outcome (and non-star players to whom a bribe could potentially be profitable are rarely in a position to influence games).

Those sports that remain at more significant risk to corruption are those with a high level of fan interest but low player salaries. This describes the working conditions of athletes prior to free-agency in the USA such as during the 1919 Black Sox scandal, referees like Tim Donaghy, and players in minor leagues or small national leagues as well as cricket players prior to the relatively recent formation of the Indian Premier League. It also describes the conditions of college athletes in the USA as the NCAA has successfully operated a cartel restricting the ability of even top college players from earning money as a player despite playing for teams generating millions or tens of millions of dollars annually for their host institutions. Thus, it comes as no surprise that the NCAA remains adamantly opposed to sport gambling in contrast to the major professional leagues in the USA.

Sports leagues are naturally eager to take steps to protect themselves against potential corruption in the wake of expanded gambling opportunities. The third paper in the symposium (Depken and Gandar 2021) explores the topic of integrity fees, payments by sports books to leagues, supposedly to pay for monitoring to ensure against match fixing. Craig Depken and John Gandar find evidence that integrity fees might influence sports books to establish lines that would minimize the chances for payouts in certain game situations.

Finally, legalized sports gambling will provide researchers with troves of new data to analyze one of the oldest questions in gambling economics: are sports betting markets efficient? The final paper in this symposium provides an excellent example of this type of research (Brymer et al. 2021). Rhett Brymer, Ryan M. Rodenberg, 
Huimiao Zheng, and Tim R. Holcomb examine whether referees in college football's major conferences can be shown to have particular biases and if these biases are appropriately accounted for in the gambling markets. Studies like these will remain a fertile area for continued economic research.

As guest editor, I wish to thank Eastern Economic Journal co-editors Cynthia Bansak and Allan Zebedee, participants in the sports economics sessions at the 39th annual Eastern Economic Association Conference in New York City, February 2019, and numerous anonymous referees for their assistance in putting together this symposium. Most importantly, thanks go out to Eastern Economic Association Vice President Brad Humphreys who both proposed this symposium and collected and reviewed the participating papers. His name should really be on this guest editor's introduction, but I guess he will have to settle to being co-author on two fine contributions within this symposium.

\section{References}

Black, Robert. 1891. The Jockey Club and Its Founders: In Three Periods. London: Smith, Elder.

Brymer, Rhett, Ryan M. Rodenberg, Huimiao Zheng, and Tim R. Holcomb. 2021. College Football Referee Bias and Sports Betting Impact. Eastern Economic Journal. https://doi.org/10.1057/s4130 2-020-00180-6.

Canymeres, Ferran. 1946. Oller: L’Homme de la belle époque. Les Editions Universelles, Paris. Translated and summarized by the University of Auckland. https://www.cs.auckland.ac.nz/historydisplays /SecondFloor/Totalisators/ToteHistory/BookSummary.pdf. Accessed 1 November 2020.

Depken, Craig A. and John Gandar. 2021. Integrity Fees in Sports Betting Markets. Eastern Economic Journal. https://doi.org/10.1057/s41302-020-00179-z.

Garrett, Thomas A., and Thomas L. Marsh. 2002. The Revenue Impacts of Cross-Border Lottery Shopping in the Presence of Spatial Autocorrelation. Regional Science and Urban Economics 32(4): 501-519.

Grote, Kent, and Victor Matheson. 2017. Should Gambling Markets be Privatized? An Examination of State Lotteries in the United States. In Sports and Betting, ed. Plácido Rodríguez, Brad Humphreys, and Robert Simmons, 21-37. London: Edward Elgar.

Humphreys, Brad R. 2021. Legalized Sports Betting, VLT Gambling, and State Gambling Revenues: Evidence from West Virginia. Eastern Economic Journal. https://doi.org/10.1057/s41302-020-00178-0.

Humphreys, Brad R., John A. Nyman, and Jane E. Ruseski. 2021. The Effect of Recreational Gambling on Health and Well-Being. Eastern Economic Journal. https://doi.org/10.1057/s41302-020-00181 -5 .

Humphreys, Brad R., Rodney J. Paul, and Andrew P. Weinbach. 2013. Consumption Benefits and Gambling: Evidence from the NCAA Basketball Betting Market. Journal of Economic Psychology 39(2): 376-386.

Jockey Club. 2020. Pari-mutuel Handle. http://www.jockeyclub.com/default.asp?section=FB\&area=8. Accessed 1 November 2020.

Matheson, Victor. 2019. The Rise and Fall (and Rise and Fall) of the Summer Olympics as an Economic Driver. In Historical Perspectives on Sports Economics: Lessons from the Field, ed. John Wilson and Richard Pomfret, 52-66. London: Edward Elgar.

Matheson, Victor, Daniel Schwab, and Patrick Koval. 2018. Corruption in the Bidding, Construction, and Organization of Mega-Events: An Analysis of the Olympics and World Cup. In The Palgrave Handbook on the Economics of Manipulation in Professional Sports, ed. Markus Breuer and David Forrest, 257-278. New York: Palgrave McMillan.

McGowan, Richard. 2014. The Dilemma that is Sports Gambling. Gaming Law Review and Economics 18(7): 670-678.

Nash, Betty Joyce. 2009. Sport of Kings: Horse Racing in Maryland. https://www.richmondfed.org/-/ media/richmondfedorg/publications/research/econ_focus/2009/spring/pdf/economic_history.pdf. 
Nevada Gaming Control Board. 2019. Monthly Revenue Report, December 2019. https://gaming.nv.gov/ modules/showdocument.aspx?documentid $=16490$.

Rodenberg, Ryan. 2020. United States of sports betting: An updated map of where every state stands, ESPN.com. https://www.espn.com/chalk/story/_id/19740480/the-united-states-sports-bettingwhere-all-50-states-stand-legalization.

Schiavon, Alessia. 2020. Youth Committee of the Italian National Commission for UNESCO. https://artsa ndculture.google.com/exhibit/the-columns-of-san-marco-and-san-todaro-comitato-giovani-della -commissione-nazionale-italiana-per-l-unesco/2wIyGE9EqYPgIA?hl=en. Accessed 15 November 2020.

Schwartz, David G. 2006. Roll the Bones: The History of Gambling. New York: Gotham.

UK Gambling Commission. 2020. Gambling Industry Statistics April 2015 to March 2019. https://www. gamblingcommission.gov.uk/PDF/survey-data/Gambling-industry-statistics.pdf.

Publisher's Note Springer Nature remains neutral with regard to jurisdictional claims in published maps and institutional affiliations. 